\title{
STUDI KASUS FAKTOR-FAKTOR YANG MEMPENGARUHI HASIL BELAJAR MATEMATIKA DI SD NEGERI 01 NANGA MERAKAI
}

\section{Dwi Cahyadi Wibowo ${ }^{1}$, Lhadyza Ocberti ${ }^{2}$, Adriana Gandasari ${ }^{3}$ 1,2,3. STKIP Persada Khatulistiwa Sintang, Indonesia.}

Email: dwicahyadiwibowo@gmail.com ${ }^{1}$, lhadiza@gmail.com $^{2}$, adrianagandasari@gmail.com $^{3}$

\begin{abstract}
The purpose of this research is to describe the factors that affect mathematics learning outcomes in class V SD Negeri 01 Nanga Merakai Academic Year 2019/2020. This research uses qualitative research methods with a qualitative descriptive approach with a case study research form. The research sample consisted of 16 student of class $5^{\text {th }}$ at public elementary school 01 Nanga Merakai. Data collection tools in the form of interview guidelines, questionnaires and documentation studies. Data analysis through several stages of data collection, data persentation, data reduction and conclusion drawing. The results showed that (1) Inhibiting factors affecting mathematics learning outcomes were divided into two factors, namely internal factors and external factors. (2) Supporting factors for mathematics learning outcomes, the research results are divided into two, namely internal factors and external factors.
\end{abstract}

Keywords: Consist of key, Mathematic learning outcomes.

\begin{abstract}
ABSTRAK
Tujuan penelitian ini untuk mendeskripsikan faktor-faktor yang mempengaruhi hasil belajar matematika di kelas V SD Negeri 01 Nanga Merakai Tahun Pelajaran 2019/2020. Penelitian ini dilakukan di kelas V SD Negeri 01 Nanga Merakai yang terdiri dari 16 siswa, yakni 12 orang laki-laki dan 4 orang perempuan. Penelitian ini menggunakan metode penelitian kualitatif dengan pendekatan penelitian deskriptif kualitatif dengan bentuk penelitian studi kasus. Alat pengumpulan data berupa pedoman wawancara, angket atau kuesioner dan dokumen. Analisis data dengan melalui beberapa tahap pengumpulan data, penyajian data, reduksi data dan penarikan kesimpulan. Hasil penelitian menunjukkan bahwa (1) Faktor penghambat yang mempengaruhi hasil belajar matematika, berdasarkan hasil penelitian dibagi menjadi dua faktor yakni faktor internal dan faktor eksternal. (2) Faktor pendukung hasil belajar matematika, pada hasil penelitian dibagi menjadi dua yakni faktor internal dan faktor eksternal.
\end{abstract}

Kata Kunci: Faktor-faktor yang mempengaruhi, Hasil Belajar Matematika

\section{Pendahuluan}

Pada era revolusi 4.0 dan globalisasi ditandai dengan berjalannya perkembangan teknologi sehingga terjadi banyak persaingan antar negara termasuk persaingan dalam menciptakan sumber daya manusia (SDM) yang berkualitas dalam beberapa aspek untuk menghadapi persaingan antar negara dan guna memajukan negara pada tujuan yang ingin dicapai. Pendidikan merupakan suatu wadah untuk menciptakan manusia yang berkualitas. UU No. 20 Tahun 2003 mengatakan bahwa pendidikan merupakan wadah seseorang untuk mengembangkan potensi dirinya dalam memiliki keterampilan, spiritual keagamaan dan perilaku yang dapat bermanfaat bagi diri sendiri, sesama, bangsa dan negara.

Pendidikan dikatakan berhasil apabila hasil belajar yang diperoleh siswa baik. Pencapaian hasil belajar merupakan aspek atau tolak ukur bahwa siswa berhasil mempelajari materi yang telah disampaikan. Hasil belajar siswa dapat dilihat dari ulangan harian, ulangan tengah semester dan ulangan umum. Dari hal ini menyatakan 
bahwa semakin baik hasil belajar, maka semakin baik pula kualitas siswa tersebut. Sehingga jika dilihat dari fenomena yang demikian, perlu diakannya proses pembelajaran dengan menggunakan metode, model, media atau strategi yang sekiranya memicu keaktifan siswa ketika proses pembelajaran berlangsung. Apabila dengan adanya proses pembelajaran yang demikian siswa dapat memperoleh pembelajaran yang bermakna, pengetahuan serta pengalaman.

Rendahnya hasil belajar matematika yang sering terjadi dapat disebabkan oleh dua faktor yakni dilihat secara internal seperti kurangnya minat, bakat, motivasi dan tingkat intelegensi siswa dalam menyimak dan memahami materi yang disampaikan selama proses pembelajaran sehingga membuat siswa selalu beranggapan bahwa matematika merupakan pembelajaran yang sukar atu sulit dipelajari. Sedangkan penyebab utama adalah faktor eksternal antara lain berupa strategi pembelajaran yang keliru, pengelolaan kegiatan belajar yang tidak membangkitkan motivasi belajar anak serta proses pembelajaran yang membawa anak untuk tidak berpikir secara kritis dalam pembelajaran maupun faktor lingkungan yang sangat memberikan dampak terhadap hasil belajar dan prestasi belajar yang dicapai siswa. Faktor lingkungan keluarga dapat memberikan dampak besar dalam proses pembelajaran anak seperti motivasi, memberikan pujian sederhana akan hasil atau pencapaian yang dicapai oleh siswa, serta mendampingi siswa dalam belajar sehingga siswa merasa diberi semangat secara intern. Penelitian Nur (2016) mengatakan bahwa memiliki perhatian orang tua berada dalam kategori tinggi dan perhatian orang tua memberikan pengaruh positif dan signifikan terhadap motivasi belajar siswa dengan besarnya pengaruh $35,1 \%$ sangat besar apabila dibandingkan dengan hasil persentase konsep diri dan persepsi terhadap matematika.

Fenomena-fenomena yang ditemukan selama melakukan wawancara di SD Negeri 01 Nanga Merakai seperti belum menggunakan metode pembelajaran yang inovatif sehingga proses pembelajaran terkesan monoton atau dengan kata lain proses pembelajaran lebih berpusat pada guru (teacher center) dan bukan pada siswa (student center).

Pada dasarnya keberhasilan pembelajaran atau di dalam siswa memperoleh nilai yang baik diperlukan adanya dorongan dari diri sendiri, lingkungan keluarga, lingkungan sekolah dan lain sebagainya yang ikut serta ambil andil sebagai faktor yang dapat memberikan hambatan atau bahkan dukungan dalam siswa memperoleh nilai tersebut.

\section{METODOLOGI PENELITIAN}

Pendekatan dalam penelitian ini menggunakan pendekatan kualitatif. Yang mana seorang peneliti memulai berpikir secara induktif, yakni menangkap berbagai fakta atau fenomena-fenomena sosial, melalui pengamatan di lapangan, kemudian menganalisisnya dan berupaya melakukan teorisasi berdasarkan fenomena yang telah diperoleh tersebut. Pendekatan penelitian kualitatid dengan bentuk penelitian studi kasus (Case Study).

Prosedur penelitian dalam penelitian ini melalui tiga tahap yakni (1) Tahap pralapangan, berupa mempersiapkan instrumen-instrumen (lembar pedoman wwawancara dan angket) penelitian yang hendak digunakan dan telah divalidasi sebelumnya guna memperoleh data yang sesuai dengan topik atau fenomena yang sedang dibahas. (2) Tahap pekerjaan lapangan, peneliti berusaha untuk menggali atau memperoleh informasi lebih dalam mengenai faktor-faktor yang mempengaruhi hasil belajar matematika yang diperoleh dari beberapa informan dalam penelitian. (3) Tahap analisis data, berupa berbagai hasil wawancara dan angket kemudian didistribusikan ke dalam 
bentuk kata-kata dan di rangkai ke dalam sebuah laporan. Penelitian ini dilakukan di SD Negeri 01 Nanga Merakai di kelas V dengan jumlah siswa sebanyak 16 siswa, terdiri dari 12 siswa laki-laki dan 4 siswa perempuan kemudian bentuk sampling yang digunakan yakni purposive sampling.

Teknik pengumpulan data yang digunakan teknik komunikasi langsung dan teknik komunikasi tidak langsung. Teknik komunikasi langsung berupa lembar pedoman wawancara yang digunakan untuk memperoleh atau melihat faktor-faktor pendukung dan penghambat siswa dalam belajar. Lembar pedoman wawancara ini di bagi kepada enam orang siswa yang sudah dikategorikan menjadi siswa yang memperoleh hasil belajar rendah, sedang dan tinggi. Hal ini dipergnakan untuk mempermudah peneliti dalam memperleh informasi yang diinginkan. Sedangkan lembar angket digunakan sebagai data pendukung mengenai pendapat atau opini siswa mengenai hasil belajar matemati apabila dinilai berdasarkan jumlah total keseluruhan siswa. Jenis angket yang digunakan adalah angket berbentuk checklist dan menggunakan skala Likert. Dalam penelitian ini keabsahan data menggunakan salah satu komponen dalam uji credibility yakni triangulasi sumber dan triangulasi teknik. Teknis analisa data menggunakan model analisis interaktif dari Miles dan Huberman (Sugiyono, 2016: 246-252).

\section{HASIL DAN PEMBAHASAN}

\section{Faktor Penghambat yang Mempengaruhi Hasil Belajar Matematika}

Faktor penghambat dalam suatu proses pembelajaran terhadap pencapaian hasil belajar dapat dilihat dan dipengaruhi dari berbagai macam sudut pandang. Hasil penelitian yang dilakukan peneliti apabila dilihat dari sudut pandang lingkungan sekolah menunjukkan bahwa guru dalam pembuatan soal masih memfasilitasi Low Order Thinking Skillss dan hanya memunculkan satu soal saja yang berbasis Higher Order Thinking Skills sehingga siswa kurang terlatih apabila diberi soal yang berupa pemecahan masalah, belum terdapat sarana dan prasarana yang memadai untuk menunjang proses pembelajaran di dalam kelas sehingga agak sulit ketika ingin membuat siswa dapat berpartisipasi aktif dalam proses pembelajaran, proses pembelajaran yang terkesan monoton atau dengan kata lain selalu menggunakan teknik ceramah dalam melakukan pembelajaran. Hal ini sejalan dengan pendapatnya Marzano (2013) menggambarkan bahwa mengelola kelas berada dalam posisi penting dalam kegiatan guru untuk membelajarkan siswa dalam mencapai hasil belajar yang diharapkan. Hal tersebut cukup masuk akal, apabila pengelolaan kelas yang buruk akan dapat menghambat belajar siswa atau tidak dapat meningkatkan hasil belajar hasil belajar siswa.

Guru juga mengatakan bahwa motivasi siswa dalam belajar belum tinggi, hal tersebut disebabkan siswa belum mendapatkan dukungan secara penuh dalam belajar, terdapat siswa yang mengidap penyakit kulit langka seperti albinisme atau albino, kondisi seperti ini dapat mempengaruhi siswa dalam belajar karena kondisi mata yang dapat menyebabkan penglihatannya berkurang apabila cahaya yang masuk ke dalam kelas terlalu kuat, terdapat orang tua yang tidak memberikan pandangan kepada anak bahwa pendidikan itu penting, siswa merasa sulit untuk mempelajari mata pelajaran matematika serta beranggapan bahwa pelajaran matematika sulit untuk dipahami. Hal ini pun dibuktikan dari hasil angket yang disebarkan kepada 16 siswa kelas V ketika diberi pernyataan sebagai berikut, " Saya merasa lebih cepat memahami ketika belajar pelajaran matematika" kemudian diperoleh persentase terbesar dalam pernyataan ini untuk kategori Tidak Setuju (TS) sebesar 43,75\% dan Sangat Tidak Setuju (STS) sebesar 25\%. Kemudian untuk pernyataan berikut yang berbunyi "Saya merasa senang 
saat proses pembelajaran matematika" dari pernyataan ini dapat disimpulkan bahwa siswa tidak merasa senang saat proses pembelajaran matematika. Hal tersebut dibuktikan dengan besar jumlah persentase siswa yang menjawab Tidak Setuju (TS) sebesar 31,25\% dan Sangat Tidak Setuju (SS) sebesar 25\%.

Dari lingkungan keluarga sangat besar dapat memberikan pengaruh terhadap hasil belajar siswa dan dapat menjadi faktor penghambat. Hal tersebut dikarenakan bahwa keluarga merupakan tempat pendidikan pertama dan utama bagi anak. Fenomenafenomena temuan yang terjadi seperti kurangnya kepedulian orang tua terhadap anaknya dalam belajar, memiliki keterbatasan ekonomi untuk memenuhi atau menyediakan waktu luang untuk mendampingi anak dan memberikan pandangan mengenai pendidikan. Hal ini sejalan dengan Seftannency, dkk (2014) yang menyimpulkan bahwa lingkungan keluarga yang baik berdampak pada pencapaian hasil belajar yang baik, sebaliknya apabila lingkungan keluarga kurang mendukung maka hasil belajar yang dicapai seseorang akan menurun dalam hal ini keluarga memegang peranan penting dalam menunjang keberhasilan belajar anak. Hal inipun didukung oleh pendapat Slameto (2013: 60-64) yang menyatakan "siswa yang belajar akan menerima pengaruh dari keluarga berupa: cara orang tua mendidik, relasi orang tua dan latar kebudayaan".

\section{Faktor Pendukung yang Mempengaruhi Hasil Belajar Matematika}

Apabila berbicara mengenai faktor pendukung hasil belajar, erat kaitannya dengan cara mengajar, bahan ajar atau materi, metode, media dan lain sebagainya. Faktor pendukung dalam hasil belajar merupakan hal terpenting yang harus dilakukan terhadap siswa. Berdasarkan penelitian di kelas V SD Negeri 01 Nanga Merakai terdapat temuan-temuan yakni siswa memiliki niat atau keinginan untuk mengulang kembali materi yang sudah disampaikan, siswa akan memperoleh nilai tinggi apabila materi yang disampaikan mudah untuk dipahami, guru menyediakan media pembelajaran walaupun tidak mampu untuk menyediakan media setiap jam pembelajaran sehingga proses pembelajaran dapat berjalan dengan lebih efektif lagi. Hal ini sejalan dengan Hotimah (2010) yang mengatakan bahwa dalam menciptakan pembelajaran yang menyenangkan dan memberikan motivasi kepada anak agar dapat berpartisipasi aktif dalam kegiaan pembelajaran sehingga terjadinya interaksi yang positif baik guru dengan siswa, siswa dengan siswa maupun siswa dengan media pembelajaran. Kemudian dengan memberikan remedial apabila nilai yang diperoleh siswa masih berada di bawah KKM, menggunakan model pembelajaran yang dapat memicu keaktifan siswa. Selain guru, orang tua siswa juga harus berperan aktif dalam proses belajar anaknya guna merealisasikan faktor-faktor pendukung. Sejalan dengan hasil wawancara yang dilakukan yakni orang tua dapat me-manage jam belajar, menyediakan fasilitas baik berupa buku pelajaran, download materi dengan memanfaatkan kecanggihan teknologi saat ini, orang tua memberikan perhatian serta masukkan kepada anak serta dapat mengontrol emosi dan menggunakan bahasa yang baik digunakan ketika berbicara kepada anak apabila hasil atau capaian belajar anak tidak sesuai dengan yang diharapkan.

\section{PENUTUP}

Berdasarkan hasil penelitian yang telah dijelaskan oleh peneliti mengenai Studi Kasus Faktor-Faktor yang Mempengaruhi Hasil Belajar Matematika Di SD Negeri 01 Nanga Merakai, maka peneliti menarik suatu kesimpulan berdasarkan hasil analisis penelitian yang telah dijelaskan, berikut adalah kesimpulannya. 
1. Faktor-faktor penghambat hasil belajar yang ditemukan berdasarkan hasil penelitian dapat dibagi menjadi dua yakni faktor internal dan faktor eksternal, faktor internal dilihat dari dua sisi yaitu sisi fisiologis (kondisi yang berhubungan dengan jasmani seperti tidak mudah menerima pembelajaran yang disebabkan oleh beberapa faktor seperti kelainan genetik) dan psikologis (suatu kondisi yang dapat mengganggu proses pembelajarn seperti minat dan motivasi) sedangkan untuk faktor penghambat eksternal yakni dilihat dari dilingkungan keluarga dan lingkungan sosial sekolah seperti materi pembelajaran yang susah untuk dipahami, jarang menggunakan proses pembelajaran yang menimbulkan semangat siswa, masih banyak orang tua yang bersikap acuh tak acuh kepada anak, tidak memberikan motivasi serta pandangan bahwa pendidikan itu merupakan hal utama yang harus diselesaikan.

2. Faktor pendukung hasil belajar dalam proses pembelajaran matematika faktor internal dan faktor eksternal dan dijelaskan bahwa faktor internal seperti terdapatnya motivasi dan minat kemudian faktor eksternal dilihat dari sudut pandang faktor lingkungan keluarga seperti pentingnya peran orang tua dalam memberikan dukungan kepada anak dalam belajar serta faktor lingkungan sosial sekolah seperti guru dapat menciptakan proses pembelajaran yang menyenangkan dan berpartisipasi aktif ketika belajar.

\section{DAFTAR PUSTAKA}

Hotimah, E. 2010. Penggunaan Media Flashcard dalam Meningkatkan Kemampuan Siswa Pada Pembelajaran Kosakata Bahasa Inggris Kelas II MI AR-Rochman Semarang Garut. Jurnal Pendidikan Universitas Garut. Vol. 04 No. 01. ISSN 1907-932X

Indonesia, R. (2003). Undang-undang Republik Indonesia nomor 20 tahun 2003 tentang sistem pendidikan nasional. Jakarta: Pemerintah Republik Indonesia.

Marzano, R.J. 2013. Seni dan Ilmu Pengajaran. Jakarta: PT Indeks.

Nur, MA. 2016. Pengaruh Perhatian Orang Tua, Konsep Diri, Persepsi tentang Matematika Terhadap Hasil Belajar Matematika Melalui Motivasi Belajar Siswa Kelas VIII SMP Negeri Di Kecamatan Ujung Loe Kabupaten Bulukumba. Jurnal Matematika dan Pembelajarannya. Vol. 2 No. 2. ISSN 2303-0992

Seftannency, dkk. 2014. Pengaruh Lingkungan Keluarga Terhadap Hasil Belajar Siswa Pada Pelajaran Ekonomi Di SMAK Abdi Wacana. Skripsi. Pontianak: Universitas Tanjung Pura.

S, Monalisa Frince. 2020. Analisis Literasi Informasi Pada Keterampilan Menulis Kritis Dan Ilmiah Mahasiswa Pendidikan Bahasa Indonesia Uhkbpnp. Jurnal Ilmiah Aquinas, Vol 3 No. 2.

Slameto. 2013. Belajar dan faktor-Faktor yang Mempengaruhi. Jakarta: Rineka Cipta Sugiyono. 2016. Metode Penelitian Pendidikan. Bandung: Alfabeta 